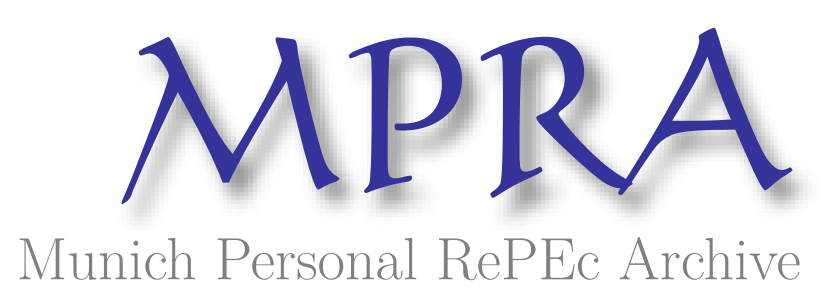

\title{
Fictitious Capital and Crises
}

Meacci, Ferdinando

University of Padova

1998

Online at https://mpra.ub.uni-muenchen.de/11761/

MPRA Paper No. 11761, posted 15 Jan 2009 03:02 UTC 


\title{
FICTITIOUS CAPITAL AND CRISES* \\ by \\ FERDINANDO MEACCI \\ Dipartimento di Scienze Economiche \\ University of Padova \\ $\mathrm{Fax}+0498274221$ \\ Email: ferdinando.meacci@unipd.it
}

\begin{abstract}
'Commerce separated the shadow from the body, and introduced the possibility of owning them separately' (Sismondi as quoted by Marx, Grundrisse, 217)
\end{abstract}

\section{INTRODUCTION}

This paper is concerned with just a section of Part $V$, The Division of Profit into Interest and Profit of Enterprise, of Volume 3 of Capital. This section does not consist of the initial chapters 21 through 24 and of the final chapter 36 of this Part (the title of which so faithfully reflects their contents), but only of the remaining chapters 25 through 35 . These chapters may be properly grouped in a separate Part the unity of which escaped Engels' attention and which is accordingly missing in the current arrangement of Volume 3 . This ideal Part (to be possibly titled Credit and Crises, or Money Capital and Fictitious Capital, and to be referred to henceforth as 'the unidentified Part') is not unrelated to what remains of Part $V$ but should be considered more strictly as a follow-up of Part IV, The Transformation of Commodity Capital and Money Capital into Commodity-Dealing Capital and MoneyDealing Capital (Merchant's Capital)' ${ }^{1}$. It should indeed be

\footnotetext{
*Published in Bellofiore R. (ed.) (1998), Marxian Economics: A Reappraisal, London: Macmillan, Vol.1, pp. 189-204.

1 The term 'commodity-dealing capital' is used in this paper for the German term Warenhandlungskapital and is thus preferred to the term 'commercial capital', which is adopted in the English translation here in use sometimes for the term Warenhandlungskapital and
} 
noted that the unidentified Part is less related to the nature of interest and to the difference between interest and profit (an issue fairly similar to the issue of rent and of the difference between rent and profit of Part VII) than to that section of Part IV where money-dealing capital is presented as a subspecies of merchant's capital. The relations between the unidentified Part and Part IV, on the one hand, and the unidentified Part and what remains of Part $V$, on the other, can be put as follows: while the analysis of interest-bearing capital (the subject of the five initial chapters of Part V) is introductory to the analysis of merchant's capital in the sense that the former is the analysis of 'capital as property as against capital as function' and the latter is the analysis of capital within the phase of circulation as a particular moment of this function; Part IV is introductory to the unidentified Part in the sense that while the former deals with the role played by merchant's capital -and particularly by money-dealing capital- in the phase of circulation as a particular moment of the overall process of reproduction, the latter deals with the obstruction or perversion inflicted on this role by money capital being turned into fictitious capital by an improper use of credit. Thus while Part IV and what remains of Part V deal with the principles of what appears to be the tail of Marx's theory of capital (the head being firmly located in Volume 1 and in its central notion of surplus-value) the unidentified Part deals with the complications created by credit and credit institutions in Marx's theory of capital when this theory is evaluated in the light of what happens, or may happen, in the real world $d^{2}$.

sometimes for the more general term Kaufmannskapital (merchant's capital).

2 While the difference between the nature of credit (Capital, Volume 1, Chapter 3) and the role of credit (Capital, Volume 3, Part V) is highlighted by Max himself, it will be maintained in this paper that one thing is to explain this role in the context of the division of profit into interest and profit of enterprise (the explicit object of Part $V$ of Volume 3); another to explain it in the context of the eruption of crises (the implicit object of the unidentified Part). On the other hand, this paper has been worded on the assumption that the reader is familiar, in general, with the distinction between 
The paper is structured in three ideal parts. The first part consists of the following 2 sections. Its aim is to clear the debris of the unidentified Part and to reconstruct Marx's own thinking about the nature and role of credit and of fictitious capital in relation to the concept of merchant's capital, on the one hand, and to the phenomenon of crises, on the other. Its conclusion is that while the role of merchant's capital is irrelevant in the context of the determination of exchange values it is either harmful or beneficial in the context of the reproduction of wealth depending on whether it does or does not give rise to (an excessive amount of) fictitious capital. On the contrary, the second part, which is mostly confined to the section dealing with different forms versus different sets of crises, highlights some contradictions in Marx's unsystematic treatment of the relations between financial and real crises. The conclusion of this part is that crises (which are relevant only in so far as they are 'real', i.e. in so far as they affect the process of reproduction of wealth) may be viewed as a disproportion between the process of circulation and the process of production (rather than between sectors). The third part is derived from the arguments set out in the previous two parts and coincides with the concluding section. The aim of this section is to assess Marx's similarity with Keynes on the matter of 'money as money' and on financial crises. Its conclusion is that this similarity, however strong with regard to the role of money as a store of value, is bound to collapse if it is considered in the light of Marx's law of the falling rate of profit, not to speak of his falling-rate-of profit theory of the breakdown. For in this case the fictitiouscapital theory of crises developed in 'the unidentified Part' acquires a secondary importance due to the fact that it is focused on a possible aspect of capitalist economies rather than on a necessary step towards their breakdown.

value and wealth (Ricardo, 1821, Chapter XX) and, in particular, with the distinction between process of circulation, process of production, and process of reproduction (see Meacci, 1989a, 1991). 
THE BENEFICIAL ROLE OF CREDIT AND OF MERCHANT'S CAPITAL IN THE REPRODUCTION OF WEALTH

At the root of the notion of fictitious capital is Marx's distinction between commercial credit and bank credit. The former is the credit that 'capitalists involved in the reproduction process' give one another through the issue of bills of exchange. The latter arises from the lending of money capital. The conditions for the existence of the two forms of credit are, accordingly, the division of labour plus the division of property amongst productive capitalists in the case of commercial credit, and between money capitalists and productive capitalists in the case of bank credit.

When Marx deals with the distinction between commercial credit and bank credit in Capital, Volume 3, he does it in the context of the process of reproduction of wealth, the wellknown object of Volume 2. The circulation of commodities (between capitalists and capitalists and between capitalists and consumers) and their production (by workers under the supervision of capitalists) are considered in this Volume as two distinct phases of this process, the most crucial difference being that surplus-value is created in the phase of production but is realized in the phase of circulation. Hence Marx's distinction between productive capital (variable and constant capital) and capital of circulation (commodity and money capital), plus his subsequent treatment of merchant's capital (commodity-dealing and money-dealing capital) as a further evolution of the capital of circulation: productive capital is to the process of production what merchant's capital is to the process of circulation, these two processes being two distinct phases of the process of reproduction. Hence the beneficial role that is normally played in this process by the two forms of credit (and by merchant's capital itself). For the role of commercial credit is to reduce the amount of money otherwise necessary to carry out a given set of transactions (with the result that, in so far as money consists of precious metals, it saves the capital otherwise necessary for the production of these metals) while the role of bank credit is to 
contribute to the creation of additional capital by concentrating in the hands of money-dealers the reserve funds of all capitalists and the money savings of all social classes. Furthermore, since merchant's capital promotes the metamorphoses of form (required for the overall process of reproduction to be completed and repeated) of commodities 'waiting to pass over into money' and of money 'waiting to pass over into commodities', its indirect function is to extend the benefits of the social division of labour to the last (and first) phase of the process of reproduction of wealth ${ }^{3}$.

The HARMFUl ROLE OF CREDIT AND OF MONEY CAPITAL IN THE REPRODUCTION OF WEALth: THE FORMATION OF FICTITIOUS CAPITAL AND THE ERUPTION OF CRISES

However beneficial the two forms of credit discussed above may be for the process of reproduction of wealth, it may well happen that they swerve from their path so as to disrupt this very process. When this disruption occurs the two forms of credit give rise to fictitious capital. The following is a reconstruction of the two meanings assigned by Marx to this concept and of the role played by fictitious capital in his theory of crises.

1. To begin with, fictitious capital should not be confused with money capital. The distinction between money capital and fictitious capital is not only different from, but it is also more advanced than, the distinction between money and money capital: while the latter distinction is instrumental to the concept of circulation as distinct from the concept of reproduction the former serves to highlight that the true object of crisis is reproduction itself. For fictitious capital

3 For a detailed discussion of these benefits see Capital, Volume 3, Chapters 16 and 19. It is interesting to note that the arguments which highlight the positive role of credit and merchant's capital in the process of creation of wealth are intertwined in Part IV of Volume 3 with the arguments which stress the irrelevant role of the same kind of capital in the process of the determination of exchange values. In this different context merchants (money-dealers and commodity-dealers) are considered by Marx in the same sense in which artificers were by the Physiocrats: they do not add anything to the value (Marx) or the matter (Physiocrats) that they receive from industrial capitalists (Marx) or fermiers (Physiocrats). 
arises any time that money capital is not employed either in production or in circulation as two distinct phases of the reproduction of wealth. Since, however, money capital must always earn an interest although it does not earn (create) a profit (surplus-value) when it is not employed in reproduction (i.e. when it becomes a fictitious capital), it follows that merchant's capital is not a form of fictitious capital. Indeed, it is true that the profit earned by merchant's capital is, as much as the interest paid on interest-bearing capital, a deduction from the profit earned by productive capital. But it should be noted that this deduction is necessary in the case of merchant's capital while it is unnecessary in the cases of interest-bearing capital and of fictitious capital; and that while merchant's capital belongs to the category of capital as function fictitious capital belongs, along with interestbearing capital, to the category of capital as property. From the point of view of reproduction, therefore, fictitious capital is not only, along with interest-bearing capital, useless. It is also, unlike interest-bearing capital, dangerous. This can best be seen in the degeneration of the two forms of credit.

2. The expansion of commercial credit is limited by the size of the process of reproduction which is in turn determined by the amount of productive capital (and merchant's capital) existing in an economy at a given time. These limits are trespassed when bills of exchange are issued, in Marx's words (Capital, Volume 3, 555), 'not to make a profit' [i.e. not in order to bring the metamorphosis of commodities one step further in the process of reproduction] but 'to get one's hands on other people's capital' [i.e. in order to interrupt the metamorphosis of commodities carried out by other people's capital]. These 'accommodation bills' are fictitious. Their existence signifies that 'the capitalist barriers to the production process' are being, or have been, violated: while the immediate appearance of this phenomenon is 'a violent scramble for means of payment', or a 'reversion' of the credit system into the monetary system (Umschlag), its root cause lies 
in the realization that the expansion of the reproduction process has been forced beyond the limits set by productive capital. When this occurs the scene is set for the eruption of crises.

The same applies to bank credit. Money capital, the typical object of this form of credit, may indeed be used either in underwriting government bonds or in multiplying bank deposits: while the money capital lent to the state is 'illusory and fictitious' from the outset (on Smith's principle, not mentioned by Marx, that governments are spendthrifts who pervert the capital they borrow) the money capital lent to (deposited at) a bank is in turn turned into nothing but a claim on the bank, and therefore again into a fictitious capital. On the other hand, the money capital subsequently lent by the bank is not fictitious only if it is employed in the purchase of means of production and labour power, i.e. in the process of reproduction of wealth.

Given the difference between money and money capital, it is however understood that the amount of money capital 'is still different from, and independent of, the quantity of money in circulation'4. For, according to Marx, the same amount of money, whatever its forms, may safely play the role of many money capitals provided that these capitals do not become fictitious, i.e. provided that these capitals are not employed

4 See Marx's example on $£ 20$ lent five times in a day (Capital, Volume 3, 194) and consider it in the light of Smith's example (quoted by Marx himself in Chapter 29) on money as a 'deed of assignment' which successively serves many different loans as well as many different purchases (Smith, 1776, 351-2). Most of the unidentified Part seems indeed to be an extension of chapters II and IV of Book II of the Wealth of Nations. Consider, for example, the expression 'with a profit' in Smith's passage above in the light of Smith's most advanced definition of productive labour (which implies that the goods purchased by debtors are employed in the process of reproduction of wealth). But also consider Smith's notions of 'real bills', 'real creditors' and 'real debtors' in the context of his treatment of over-trading based on the 'well-known shift of drawing and re-drawing' which leads to 'fictitious' payments and which, 'without increasing in the smallest degree the capital of the country', would only transfer 'a great part of it from prudent and profitable to imprudent and unprofitable undertakings' (1776, Book II, Chapter II). For a survey of the uses of the term 'fictitious' 
outside the process of reproduction; or, to put it in smith's terms, provided that 'the goods purchased by the different debtors' are 'so employed, as, in due time, to bring back, with a profit, an equal value either of coin or of paper' (Smith, $1776,352)$.

3. However unsuited for Engels' Part $V$ of Volume 3 of Capital, Marx's treatment of fictitious capital fits into the structure of this Volume as properly as other topics such as the transformation of values into prices, or profit, interest and rent as three distinct forms of surplus-value. For the general aim of Volume 3 is the study of one-capital-inrelation-to another (or of the property of someone in relation to the property of someone else) and not of capital-in-general (or of capital in relation to labour). This context makes it easier to grasp Marx's second definition of fictitious capital. This definitions is derived from his arguments concerning i) the similarity between fictitious capital and the value of land; and ii) the relation between fictitious capital and capitalization.

The link between these two topics is made explicit in the passage of Volume 3 where Marx, speaking of the price of a waterfall as 'an irrational expression', concludes that this price 'is nothing more than capitalized rent' (Capital, Volume 3, 787), and in the other passage where he flatly states that 'the formation of fictitious capital is known as capitalization' (Ibid., 597). The similarity between these two statements is to be traced to the fact that what is at stake in both cases is the value of a title of ownership (or, to put it in more current terms, the value of an asset) rather than the value of a commodity; and that, the value of the title being determined by different principles (discounting) than the value of the commodity (labour embodied), the movement of the former 
is determined by different rules than the movement of the latter ${ }^{5}$.

In this new perspective fictitious capital may be re-defined as the value of ownership titles: this value is a 'pure illusion' if only because its connection with the world of commodities (and particularly with the labour embodied in them) is lost even when it does not consist of government bonds. According to this new definition, capital is fictitious not because it is created beyond the constraints set by the actual process of reproduction (as implied by the first definition), but because its value is formed in contrast with the principles of the labour theory of value. However incoherent with one another, these two definitions are nonetheless useful in understanding, if taken together, that it is an excessive growth of fictitious capital, and not fictitious capital as such, that constitutes a condition of crises; and, if taken apart, that money capital and capital value are two distinct concepts: while the former is a transitional form of capital when the process of reproduction is considered in the context of the division of property, the latter is a fiction by which accountants and businessmen make circulation possible also between ownership titles and money.

DIFFERENT FORMS VS. DIFFERENT SETS OF CRISES

Marx's talent for distinguishing between 'essence' and 'appearance' is particularly evident in chapter XVII of Theories of Surplus-Value (TSV) where it gives rise to the distinction between the possibility (or conditions) and the actuality (or causes) of crises. Neither in this chapter, however, nor in Volume 3 of Capital was Marx able to present a systematic theory of this phenomenon. For instance, while chapter XVII is silent about the role of fictitious capital the

5 A theory of capital as the value of ownership titles (capitalvalue) was fully developed by Irving Fisher (1906). Fisher, however, conceived of his theory in contrast with, rather than in continuation of, the theory of the classics (Meacci, 1989b). From this perspective Marx's brief treatment of capitalization can be viewed as a sort of a bridge between the two theories. 
unidentified Part of Volume 3 is not as explicit as this chapter is on the different forms of crises: it is as if this Part dealt with just one of these forms, i.e. with the form originated by fictitious capital. In TSV, however, Marx starts from the phenomenon of over-production as an interruption in the reproduction process and regards this phenomenon as the 'general condition' of crises (i.e. the factor which turns their possibility into actuality). Crises, on the other hand, are here presented as monetary crises, the forms of which are essentially two: one is originated by money functioning as means of circulation (and therefore by the separation of purchase and sale); the other (which gives rise to what would be called today financial crises) by money functioning as means of payment (and therefore by the separation in time between purchase and sale) (TSV, II, 514).

Although fictitious capital is not mentioned in TSV, the arguments of Volume 3 of Capital make it clear that this form of capital corresponds exclusively to the second function of money. From the standpoint of the relation between production and circulation it results, however, that fictitious capital is originated, according to the arguments of Volume 3, by the process of circulation outgrowing the process of production (through what Marx calls 'excess credit') and, according to the arguments of TSV, by the process of production outgrowing the process of circulation (through what Marx calls 'overproduction'). Far from contradicting each other, these two sets of arguments may be used to stress the unity of Marx's theory at least in the sense that in both cases a crisis presents itself as a disturbance in the process of reproduction as well as the solution of a contradiction between production and circulation: its function is either to bring the process of circulation back into line with a given process of production, or to bring he process of production back into line with a given process of circulation.

The idea of the crisis as the outcome of a disproportion between processes (rather than between sectors) paves the way to a settlement of the question of the relation between money 
crises and real crises, i.e. between two different sets of crises rather than between two different forms within one of these sets. It also paves the way to the further question of the much broader relation between what may be called the Fictitious-Capital Theory of Crisis (FCTC), as developed in the unidentified Part, and the most crucial (in Marx's system of thought) Falling-Rate-of Profit Theory of Crisis (FRPTC), not to speak of the Falling-Rate-of-Profit Theory of the Breakdown (FRPTB). An attempt to provide a solution to the first question was made by Engels in a note added to the third German edition of Volume 1 of Capital ${ }^{6}$ :

'The monetary crisis, defined in the text as a particular phase of every general industrial and commercial crisis, must be clearly distinguished from the special sort of crisis, also called a monetary crisis, which may appear independently of the rest, and only affects industry and commerce by its backwash. The pivot of these crises is to be found in money capital, and their immediate sphere of impact is therefore banking, the stock exchange and finance' (Capital, Volume 1, 236, n.50).

Engels' insight may be re-formulated in the sense that financial crises are sometimes the cause and sometimes the effect of real crises. In view of what was argued above, however, it should be noted that when financial crises are the cause of real crises their pivot is not to be found, contrary to Engels' claim, in money capital as such, but in its degenerate form of fictitious capital; and not even in fictitious capital as such, but in its excessive growth.

\section{CONCLUDING REMARKS}

In the light of Shackle's dictum concerning the essence of Keynes's thought, namely that 'the fox knows many things the hedgehog knows one big thing' (1967, 135), one may wonder at this point whether the 'one big thing' that Keynes knew, i.e. that money is a store of value and therefore a vehicle of

6 This idea returns elsewhere in Marx's work. See for instance Capital, Volume 2, Chapter 16. 
uncertainty, was known to Marx himself ${ }^{7}$. From the arguments set out so far it follows i) that this is indeed the case ${ }^{8}$ and ii) that Marx dealt with this issue in the sophisticated framework which he had derived from the Physiocrats and the classics (and which was rather neglected by keynes) of the process of reproduction of wealth. This conception of money is indeed at the root not only of Keynes's and Marx's common negation of Say's law (Keynes, 1936, 26; Marx, TSV, II, 492-535) but also of their view of a monetary economy as distinct from a realexchange economy (Keynes, 1933a) or, again in Keynes's words, of an entrepreneur economy as distinct from a co-operative economy (Keynes, 1933b) ${ }^{9}$. In this sense not only did Marx deal with money as a store of value, but he did it in the context of what Schumpeter $(1954,291-2)$ considers a condition for 'any satisfactory theory of money', i.e. in the context of 'a theory of the economic process in its entirety ${ }^{10}$.

7 Shackle (1967) admirably shows not only the ultimate consequences that can be traced to money as a store of value in an economy plagued by uncertainty, but also the role assigned to this aspect of money in the whole structure of Keynes's theory. On the 'nice congruence' between Keynes's treatment of money as 'a bottomless sink of purchasing power' and Marx's statement that 'the desire after hoarding is in its very nature insatiable' see Dillard (1984). On Marx's treatment of 'money as money' and of the hoard as 'constantly in tension with circulation' see Arnon (1984). On Keynes's theory of effective demand in a monetary economy as an 'actuality' (rather than 'possibility') theory see Kenway (1980).

8 Further evidence can be found in the Grundrisse (see Marx's arguments about the 'third function of money', or about money as the aim rather than as the medium of circulation) and in the Theories of Surplus-Value (see Marx's arguments about the 'subterfuge' by which the 'exchange of products' is misunderstood by economists for the 'circulation of commodities' although 'the motive to turn the commodity into money' often prevails over 'the motive to transform the commodity again into use-value').

9 In this study, which was probably intended for the for first chapter of the General Theory, Keynes's 'entrepreneur economy' is explicitly referred to Marx's formula for capitalist production M-C$M^{\prime}$ as distinct from simple production C-M-C'. It should be noted, however, that while the movement $\mathrm{M}-\mathrm{C}-\mathrm{M}^{\prime}$ is regarded by Keynes as typical of an 'entrepreneur economy' Marx's very distinction between the movement $\mathrm{M}-\mathrm{C}-\mathrm{M}^{\prime}$ and the abbreviated movement $\mathrm{M}-\mathrm{M}^{\prime}$ may be equally regarded as an introduction to Keynes's further distinctions between industry and finance (Keynes, 1930, V, Chapter 15) and between enterprise and speculation (Keynes, 1936, Chapter 12).

10 It is curious that, in spite of this insight, schumpeter fails to see behind Marx's own theory 'a theory of the economic process in 
It should be noted, however, that Marx can be regarded as a precursor of the monetary (keynesian) theory of production, and of the modern theory of crisis that goes with it, only in so far as he is exclusively regarded as the author of the unidentified Part, as singled out in the introduction above and as distinct not only from Part $V$ but also from other Parts of Volume 3. For not only is the FCTC (the implicit object of the unidentified Part) essentially unrelated to the theory of the division of profit into interest and profit of enterprise (the explicit object of Part V); it also runs counter the FRPTC (the object of Part III) let alone, via Marx's arguments on the necessity of real crises, the FRPTB. Indeed, while the FCTC deals with financial crises as the cause of real crises, the FRPTC and FRPTB do the opposite: they tend to deal with financial crises as the effect of real crises while they focus on real crises as the essential outcome of a continuous process of accumulation. In this sense the FRPTC and the FRTB pose a dilemma for those who still believe (as Marx and Engels may have thought in order to make these theories consistent with the FCTC) that financial crises are the typical effect of real crises: they either accept the FRPTC and FRPTB -and therefore reject the modern theory of crises; or they accept this theory -and therefore reject the FRPTC and FRPTB.

\section{REFERENCES}

ARNON A. (1984), 'Marx's theory of money: the formative years', History of Political Economy, 16:4, 555-75

DILLARD D. (1984), 'Keynes and Marx: a centennial appraisal', Journal of Post Keynesian Economics, VI:3, 421-32

FISHER I. (1906), The Nature of Capital and Income, New York: Macmillan

KENWAY P. (1980), 'Marx, Keynes and the possibility of crisis', Cambridge Journal of Economics, 4, 23-36

KEYNES J.M. (1930), A Treatise on Money, in D. Moggridge (ed.), The Collected Writings of John Maynard Keynes, Vols. V-VI, London: Macmillan, 1971

\footnotetext{
its entirety' and limits himself to dealing with him as a
} 'theoretical metallist' (Ibid., 699). 
KEYNES J.M. (1933a), 'A Monetary Theory of Production', in D. Moggridge (ed.), The Collected Writings of John Maynard Keynes, Vol.XIII, The General Theory and After. Part I: Preparation, London: Macmillan, 1973, 408-11

KEYNES J.M. (1933b), 'The Distinction Between a Co-Operative Economy and an Entrepreneur Economy', in D. Moggridge (ed.), The Collected Writings of John Maynard Keynes, Vol. XXIX, The General Theory and After: A Supplement, London: Macmillan, 1979, 76-87

KEYNES J.M. (1936), The General Theory of Employment, Interest and Money, London: Macmillan, 1964

MARX K. (1867), Capital, Volume 1, Harmondsworth: Penguin, 1976

MARX K. (1885), Capital, Volume 2, Harmondsworth: Penguin, 1978

MARX K. (1894), Capital, Volume 3, Harmondsworth: Penguin, 1981

MARX K. (1905), Theories of Surplus-Value, 3 Volumes, London: Lawrence \& Wishart, 1968-72

MARX K. (1939), Grundrisse, Harmondsworth: Penguin, 1973

MEACCI F. (1989a), 'Different Divisions of Capital in Smith, Ricardo and Marx', Atlantic Economic Journal, 17, 13-21

MEACCI F. (1989b), 'Irving Fisher and the classics on the notion of capital: upheaval and continuity in economic thought', History of Political Economy, 21, 409-24

MEACCI F. (1991), 'The organic composition of capital and the falling rate of profit', in G. Caravale (ed.), Marx and Modern Economic Analysis, Volume II, Aldershot: Edward Elgar, 85-109

PERELMAN M. (1987), Marx's Crises Theory. Scarcity, Labor and Finance, New York: Praeger

RICARDO D. (1821), Principles of Political Economy and Taxation, in P. Sraffa (ed.), The Works and Correspondence of David Ricardo, Cambridge: Cambridge University Press, $1951-73$

SCHUMPETER J.A. (1954), History of Economic Analysis, London: Routledge, 1994

SHACKLE G.L.S. (1967), The Years of High Theory. Invention and Tradition in Economic Thought 1926-1939, Cambridge: Cambridge University Press

SMITH A. (1776), An Inquiry into the Nature and Causes of the Wealth of Nations, Oxford: Clarendon Press, 1976 